\title{
Exploring the Instructional Supervision Practices of School Principals in the Midlands Province of Zimbabwe
}

Willard Nyathi ${ }^{1 *}$, Caxton Shonhiwa ${ }^{2}$

${ }^{1}$ Dean Faculty of Education, Amadi University

${ }^{2}$ Senior Lecturer, Faculty of Commerce, Zimbabwe Open University

DOI: $10.36347 /$ sjahss.2020.v08i09.007

| Received: 03.09.2020 | Accepted: 10.09.2020 | Published: 25.09.2020

*Corresponding author: Willard Nyathi

\section{Abstract}

This study sought to assess the instructional supervision practices of school principals in the Midlands Province primary schools in Zimbabwe. The study employed the mixed methods research methodology and adopted pragmatism as its philosophy and triangulation as its design. The sample comprised of eight-nine respondents and participants who were randomly and purposively selected. The study's data collection and generation instruments were the questionnaire and the interview guide. Data from documents complemented data from the two major instruments. The study revealed that supervisors were not prioritising class visits as a result of many competing programmes on their itineraries. The study also revealed that instructional supervisors were overloaded with a multiplicity of chores which distracted them from carrying out effective instructional supervision. In terms of models of supervision, it emerged that the instructional supervisors had vast knowledge about various models of supervision, and yet it was clear that they were not using any specific model. They inevitably resorted to what was feasible within the context of their operations; which unfortunately is not enough for effective instructional supervision. The researcher recommends that instructional supervisors should prioritise their operations so that the bulk of their working time is taken up by instructional supervision related activities. The study also recommends that instructional supervisors should use supervision models that encourage interaction between the supervisor and supervisee and should not promote faultfinding or supervisor dominance during the instructional supervision process.

Keywords: Instructional Midlands Supervision.

Copyright @ 2020: This is an open-access article distributed under the terms of the Creative Commons Attribution license which permits unrestricted use, distribution, and reproduction in any medium for non-commercial use (NonCommercial, or CC-BY-NC) provided the original author and source are credited.

\section{INTRODUCTION}

Schools in developing countries face a host of problems related to the twin concepts of poor classroom instruction and low student achievement [1]. Developing countries face common problems in providing sufficient education of high quality to their learners. Typically, these challenges breakdown to matters of instructional supervision, teaching behaviours and general learner performance [2]. Given this context, it becomes necessary to construct new frameworks in the following aspects: teacher effectiveness, progressive models of supervision and effective leadership styles. Accordingly, the search for instructional supervisory strategies that can deal with the lesson delivery capacities of teachers and poor performance of students of developing countries should be intensified [3]. In the process of improving teacher instructional competencies, many educators have come to realise that the quality of instruction depends not only on teachers but on principals as well. Principals have the responsibility of assisting teachers in making decisions regarding the quality of their instructional competencies. Yet, they (principals) often lack the necessary skills to provide teachers with the help they need to develop instructionally. Madziyire [4] quotes Nyagura and Reece [5], who contend that "... in quite a number of schools due to a shortage of trained teachers, inexperienced teachers have been placed in supervisory roles.

Ozigi [6] advises that "principals require conceptual skills in supervision in its broadest sense in order to ensure that they fully understand what their roles and tasks as supervision of schools are". Lack of supervisory skills may result in conflict between teachers and supervisors when teachers feel unfairly treated. One way of improving the teacher-supervisor relationship therefore, is thorough supervisor training. In this regard, Harber and Davies [6], note that in developing countries, principals of schools emerge from 
the teaching population and have had little or no training for the job. They argue that "a major concern for school management debates in recent years has been the need to train principals" [7]. Marks [8] concur when he argues that "principals are chosen because they are good at one thing (teaching) and put into managerial roles which can demand quite different skills".

Ndebele [9] observes that "...it is perhaps in this context [portraying a lack of principal's supervisory skills] that most teachers are apprehensive about being supervised; they appear to be dissatisfied with supervisors' classroom observations, hence the negative views towards instructional supervision”. McLaughlin [10] quoted in Madziyire [4] comments that most teachers place several charges against classroom observation by supervisors. They critics it for being infrequent and unreliable. This is corroborated by Marks [8] who postulate that many teachers fear a visit by the supervisor often with good reason. They dislike having to defend methods and techniques which they found successful. Teachers object to being told what to do.

\section{LITERATURE REVIEW Conceptual Framework}

The conceptual framework of this study was in two parts. The first part detailed the three major issues which impacted directly on instructional supervision; which are, the decline in learner performance; the basic skills and capacities of instructional supervisors and the work load of these supervisors. These issues are referred to in the conceptual framework as the primary or major challenges because they formed the basics of the entire study; that is, they encompassed the issue that prompted the researcher to engage in this study namely; assessing the role of instructional supervision on the performance of teachers and learners.

The second part of the conceptual framework provided an overview of the four variables under which instructional supervision is conceptualised in the literature. These variables are; promoting frequent and appropriate school-wide teacher development activities, defining and communicating a shared vision as well as goals, monitoring and providing feedback on the teaching and learning processes, and managing the curriculum and instruction to respond to challenges faced by instructional supervisors. These issues are referred to as secondary challenges because, whilst their purpose is to address learner performance, there is actually no compatibility between them and the traditional role of the instructional supervisor [11].

\section{THEORETICAL FRAMEWORK}

The research was guided by the collegial theory propounded by Caroll [12] Collegial theory of education supports the notion of shared power within the organisation. Members of the organisation engage in discussion in order to reach consensus when making decisions. Teachers work collaboratively under this theory of supervision. The model requires participation from all stakeholders in the school. One of the drawbacks of this theory is that the decision making process can be slow and complicated. One major benefit of the theory is that it allows for the involvement of stakeholders at all levels, connecting them to the welfare of the institution. In a collegial leadership model, policies are determined and decisions are made through a process of discussion leading to a consensus [3]. There is power sharing based on expertise and, mutual understanding of the school's shared vision.

The authority of expertise advocated by a collegial approach encourages teachers to collaborate through shared values and establish decision-making skills based on their expertise. This implies that teachers should be held accountable when they are included in the decision-making process in a meaningful and collegial manner [13]. Collegial strategies can therefore be associated with the demonstration of professional behavior towards colleagues, based on attitudes and virtues that are enshrined in the school's shared vision. Collegiality, therefore, may be described as the way in which teachers and instructional supervisors share common values, common goals, accountability and a sense of trust built on the foundation of congeniality [13]. In a collegial leadership model, the imposition of decisions on staff is morally unjustifiable and inconsistent with the notion of consensus [3].

\section{EMPIRICAL STUDIES}

\section{The nature of instructional supervision}

Sergiovanni and Starratt [14] argue that "the ultimate purpose of supervision is the promotion of pupil growth and hence eventually the improvement of society". Supervision, through all means available, will seek improved methods of teaching and learning. It works primarily in the area of instructional improvement. It is concerned with improving the setting for learning in particular. Supervision is critical to the continuation of quality schooling. Ndebele [9] is of the opinion that "a good supervision programme demands supervisors who are continually striving to improve by growing with their teachers".

Contrary to the above noble purposes of supervision, supervision has sometimes not been useful to teachers. Findings by Moyo [15] on the effectiveness of supervision in Hwange, Zimbabwe reveal that:

Supervision was found to be meaningless, wearisome and frustrating to teachers' critiques produced were biased. They only contained the supervisor's views. This rendered the discussion after lesson observations useless as supervisee's views were not considered. 
Harris [16] posits that "...instructional supervision is meant to improve the teachers' instructional ability". The supervision is expected to work with the teachers in lesson planning preparation, presentation and evaluation.

\section{The role of the instructional supervisor}

In Zimbabwe, the head of school is the main instructional supervisor at school level. Olivia [17] (in Beach and Reinhartz, [18] asserts that "the term instructional supervisor is used to refer to any individual regardless of title who functions in a supervisory position in the education system". Wiles and Bondi [19] (in Beach and Reinhartz, [18] echo similar sentiments when they assert that "an instructional supervisor is someone who is formally designated by the education system who has the responsibility for working with teachers to improve the quality of pupil learning through improved instruction". While there may be other supervisors of instruction in the Zimbabwean education who include education officers, provincial education directors and others, this study concentrates on school heads or principals as they are at the supervisional centre of the learning / teaching process at the school level.

Beach and Reinhartz [18] have summarised the role of the supervisor as planner, organizer, leader, helper, appraiser, and communicator and decision maker. Planning involves the ability to determine in advance what should be done and how it is to be accomplished. A good example would be helping teachers with time management strategies as they plan their lessons. The ability to organise is also a prerequisite for the supervisor. Olivia [17] says that "Linking people with the necessary resources is vital to the effective operation of the school".

In order to be successful, an instructional supervisor must be able to influence the behaviour of others. For example, the supervisor must be able to persuade teachers to modify their lesson plans or change their teaching behaviour to accommodate individual students. The primary objective of supervision according to Beach and Reinhartz [18] "is to help to improve and develop teachers' instructional skills".

Supervisors, as they work with teachers, should keep in mind the climate of the school, the need for collective dialogue and the teachers' involvement in determining the goals and types of supervision they would like to have. In this regard Beach and Reinhartz [18] argue that "...school improvement begins with supervisors using the pre-requisite skills in human relations, organisational behaviour and management as they talk openly with teachers about problem areas".

\section{Effective teaching behaviours}

Instructional supervisors must be aware of the complexities associated with effective teaching. Joyce and Showers [20] state that "...supervisors knowledgeable about teaching and effective teaching behaviours can establish an instructional mind or frame of reference as they help teachers increase their ability to reach more students by providing a rich and diverse environment". Greenblatt, Cooper and Muth [21] provide a list of what they think is effective teaching behaviours. These include, daily review of previous work, direct instruction, being actively engaged in learning, corrective feedback, guided and independent practice, Instructional clarity, time on task, teacher keeps students engaged during instruction, questioning, varies instruction, states expectations, as well as classroom management and organisation [21].

These behaviours are concrete images of what successful teachers do and should be considered within the overall context of the classroom. However, Griffin [22] says that "...caution should be sounded against over-generalisation about these behaviours, because the research studies are often situation, and student specific. Nevertheless, as Beach and Reinhartz [18] conclude: "...there are representative correlational studies from state-of-the-art data that have consistently identified the same qualitative skills that effective practitioners use to increase student achievement". Other authorities do concur with Greenblatt, Cooper and Muth [21] on the general skills of practitioners. A twelfth skill is added to the list, which is "enthusiasm and interest" [the amount of the teachers' vigour and power] [23].

\section{PURPOSE OF THE STUDY}

The study's main purpose of the study was to assess the instructional supervision practices of school principals in Matabeleland North's primary schools in Zimbabwe. The two main objectives that guided the study were:

- To stablish the effectiveness of instructional supervision in primary schools, and

- To proffer suggestions for the improvement of the instructional supervision process in primary schools to improve the performance of teachers and ultimately that of learners.

\section{RESEARCH METHODOLOGY}

The study used the mixed methods methodology. There is an ongoing debate concerning the most appropriate approach of research inquiry in the social sciences generally, and in educational research in particular. A review in literature points to the fact that the debate centres around the paradigms which guide and inform research in the social sciences, in particular, data collection or generation methods and trustworthiness of the research findings [23, 24, 22, 25]. These "paradigm wars", as Bailey [24] refers to the debate, revolve around the dominant approaches, namely, the quantitative and qualitative traditions. 
Capturing the essence of this debate, House [26] claims that for some time now, the educational research community has been in fervent debate over the proper approach to research. Meighan [27] contends that the debate is mainly about research techniques or methods on the one hand, and paradigms, methodology or strategy on the other. This study makes use of the mixed methods research approach which as Babbie [28] posits, is a research design with philosophical assumptions as well as methods of inquiry. As a methodology, it involves philosophical assumptions that guide the direction of the collection and analysis of data and the mixture of qualitative and quantitative approaches in many phases in the research process [29, $27,28,30]$. As a method, mixed methods research focuses on collecting, analysing and mixing both quantitative and qualitative data in a single study or series of studies [31]. Its central premise is that the use of quantitative and qualitative approaches in combination provides a better understanding of research problems than either approach alone [32].

Mixed methods research begins with the assumption that investigators, in understanding the social and health worlds, gather evidence based on the nature of the question and theoretical orientation [21]. Social inquiry is targeted toward various sources and many levels that influence a given problem (like policies, organisations, family, individual). Quantitative (mainly deductive) methods are ideal for measuring pervasiveness of "known" phenomena and central patterns of association including inferences of causality [33]. Qualitative (mainly inductive) methods allow for identification of previously unknown processes, explanations of why and how phenomena occur, and the range of their effects [34]. Mixed methods research, then, is more than simply collecting qualitative data from interviews, or collecting multiple types of quantitative evidence (for example, surveys and diagnostic tests). It involves the intentional collection of both quantitative and qualitative data and the combination of the strengths of each to answer research questions [19].

\section{Population}

This study's population comprised all primary school heads, grade seven teachers, district education officers and education inspectors in the Midlands Province. Midlands Province is one of the ten provinces in Zimbabwe. In terms of central government administration, a province in Zimbabwe is headed by provincial administrator, who is the most senior civil servant in the province. Educationally, a province is overseen by a Provincial Education Director who is deputized by two deputy provincial directors; one representing the primary sector and the other, the secondary sector. Midlands Province is further divided into eight administrative districts, namely, Chirumanzu, Kwekwe, Gweru, Gokwe North, Gokwe South, Shurugwi, Zibagwe and Zvishavane. Each district has the District Schools' Inspector as its educational head under which, Education Inspectors, heads of schools and teachers fall.

\section{Sample and sampling procedures}

To address a research question or hypothesis, the researcher decides which people and research sites can best provide information, puts a sampling procedure in place, and determines the number of individuals that will be needed to provide data [19]. Since this study adopted the mixed methods research which combines the quantitative and qualitative approaches, the sampling procedures used reflected the existence of the two paradigms within the study. For the qualitative dimension of the study, the researcher purposefully selected individuals and sites that provided the necessary information. Homogeneous sampling strategy which is a type of purposive sampling was used to come up with participants who have experience with the central phenomenon or the key concept being explored by this study, which is, instructional supervision practices of principals. The researcher deliberately selected a small number of participants that provided indepth information about each person or site. This is because as Patton [34] states, the larger the number of people, the less the amount of detail typically emerging from any one individual; and yet a key idea of qualitative research is to provide detailed views of individuals and the specific contexts in which they hold these views.

In quantitative research, the intent of sampling is to choose individuals that are representative of a population so that the results can be generalised to a population [29]. In this study. a random choice of individuals for the sample was attempted so that each person in the population had an equal chance of being selected [25]. Probabilistic sampling which involved random numbers table was employed.

\section{Data collection / Generation Instruments and Procedures}

Since this study used the mixed methods research methodology, it therefore used methods that collected quantitative and generated qualitative data respectively. For the quantitative data collection, the survey questionnaire was largely used; and for the qualitative data generation, the study employed the face to face interview. Document analysis was also used to complement information collected and generated from the questionnaire and the interview.

\section{Ethical Considerations}

In order to adhere to all ethical considerations and guidelines for conducting research with human subjects who were primary school teachers and educational officials from the Ministry of Primary and Secondary Education, the first stage involved gaining of official permission to undertake the research in the organisation, from the Permanent Secretary of Ministry 
of Primary and Secondary Education. An application letter along with all necessary documentation regarding the nature and purposes of this study was submitted to the Ministry of Primary and Secondary Education seeking their approval of this study. Justification of the procedures which raised any ethical concern were made. This stage of access and acceptance at that point was important because it afforded the best opportunity for the researcher to present his credentials as a serious investigator and establish the researcher's ethical position with respect to the proposed research. Access in this study did not present a problem because the survey presented a one off commitment. Having identified the official and significant figures whose permission were to sought, the researcher needed to clarify the precise nature and scope of the research and how best the findings would be disseminated. By such planning and foresight, the researcher obtained a good idea of the demands likely to be made on both the participants and their organisations. It was a good opportunity to anticipate and resolve likely problems, especially of practical kind like disruptions of day to day duties, time management and venues.

\section{FINDINGS AND DISCUSSION}

\section{How often do instructional supervisors carry-out the role of evaluating and appraising teachers?}

Generally, internal supervisors (heads and deputy heads of schools) conducted class visits either once or twice per teacher per term. External supervisors (inspectors) may come once per year or twice per teacher per term. External supervisors (inspectors) may come once per year or after three years. Although the teachers concurred with their internal supervisors that they carried out instructional supervision once or twice per term per teacher they went on to explain that these visits were "whirlwind" in nature in that the supervisor came in for a few minutes and set behind the classroom and left before the end of the lesson or was interrupted by a parent or visitor a few minutes after the start of the lesson and left for good. There was no feedback and sometimes there was no supervision krit or report that was produced. For the external supervisors, the tendency was to use heads of schools from other districts who would be working in hand with the few inspectors from the districts. They too, spent very little time with the teachers as they were always rushing to cover all the schools within their itinerary. This too, like the internal supervision, did not render any help to the teachers. Instructional supervision (also referred to as classroom visits) is a very crucial activity because when supervisors visit classrooms and spend time in the classrooms in order to understand what learners are learning and what teachers are teaching, and actually participate in the teaching / learning process; they set a positive tone that will lead to improvement in the performance of the learners [7].
In a study conducted by Glickman [10], one supervisor (instructional supervisor) made the following comments about his / her day at school:

I visit each classroom. The opportunity to be present in the classroom everyday gives me insight into the student and teacher dynamics that drive the school climate and culture. I also observe the components of individual student learning and engagement. At first, the teachers were really uncomfortable with the frequency of my visits, but overtime, they realised that it was "style" to gain a better understanding of what is going on with students and staff. This greatly helped to improve the performance of both my teachers and pupils in the long run.

The situation above demonstrates that when an instructional supervisor increases his / her visits to classrooms for lesson observations, in the long run, it helps to improve the performance of both teachers and their pupils. However, this scenario is very different from what obtains in Matabeleland North Province as evidence reveal that the instructional supervisors, both internal and external hardly have spare time to visit classrooms on a daily basis.

As a result of the frequency and nature of carrying out instructional supervision in the schools' understudy, it came as no surprise when most of the teachers stated that they did not benefit from the class visits carried out by their supervisors. Teachers indicated that it was the most boring routine that had no impact at all to their performance as it did not bring about any new ideas. The reasons for this situation could be attributed to the fact that supervisors sometimes do not understand what instructional supervision is all about.

In the light of the above, instructional supervision carried out by Zimbabwean principals is inadequate and not helpful for the professional growth of the teachers. This is consistent with findings by Madziyire [4] who capture how most teachers seem to feel about the classroom visits made by supervisors:

... what frustrates me more about this so called instructional supervision is that the principals come into my class once a term for some few minutes. It is a scary unpleasant experience. I would not mind if 1 was being supervised by someone who's been a success in the classroom, but usually its someone who was a poor teacher who was pushed in an administrative position and to top it off, that person usually has had no training whatsoever in how to effectively supervise.

There is need for supervisors to make instructional supervision their number one goal so that they spend more quality time with teachers and pupils 
in the classrooms for the betterment of the teaching / learning process.

\section{Promotion of good behaviour of teachers through instructional supervision}

The findings from the study reveal that much as supervisors were aware of the importance of changing teacher behaviours in order to improve the performance of the teachers, the instructional supervisors understudy, seemed not to demonstrate the capacity to perform this task. The respondents were almost in total agreement that the frequent and sometimes sporadic visits by supervisors to observe teachers as they delivered lessons, did not have an effect of changing teacher behaviours in a positive way. The instructional supervisors did not play the role of recording relevant behaviours of teachers and children as the lesson progressed.

It is important that instructional supervisors are aware of the complexities associated with effective teaching. As Joyce and Showers [20] state:

Supervisors knowledgeable about teaching and effective teaching behaviours can establish an instructional mind, or frame of reference as they help teachers increase their ability to reach more students by providing a rich and diverse environment.

Effective teachers possess or exhibit certain behaviours that promote effective teaching and learning, and instructional supervisors should help teachers without these behaviours to develop them through the guidance they provide during the classroom visits for lesson observation. These behaviours are according to Griffin [22], concrete images of what successful teachers do and should be considered within the overall context of the classroom. Beach and Reinhartz [18] state that there are representative correlational studies from state of the art data that have consistently identified the same qualitative skills that effective practitioners use to increase student achievement.

The findings reveal that instructional supervisors had no time to record relevant behaviours of teachers and children as the lesson progressed especially, the positive behaviours. The tendency was to highlight the negative ones if ever an opportunity presented itself for the instructional supervisor to record a behaviour.

\section{Challenges experienced by instructional supervisors}

The findings reveal that the major challenges that instructional supervisors experienced include shortage of resources, work overload, poor models of supervision as well as role conflict between supervisor (colleague) and administrator (superordinate). All the respondents / participants agreed that instructional supervisors experienced a number of challenges that negatively affected their effectiveness and thus, weakened their role of assisting teachers in their classroom delivery to improve performance of pupils. This finding tallies with observations by Nyagura and Reece [5] who state that:

Besides the administration of the whole school, the instructional supervisor of a primary school is expected to supervise all his/her teachers including the deputy head. In addition, the head or principal is in the middle of the relationship between teachers and external ideas and people. As in most human triangles, this also brings about constant conflicts and dilemmas.

The above information emphasises the many roles of a school supervisor and how they impact on his / her efforts towards instructional supervision. The supervisor in Matabeleland North, have a number of chores that eat a lot of their time at the expense of instructional supervision. Most of their time they will be having visitors from within or without the community. Some of the visitors will be significant people within the community and the principal could not delegate any of his / her subordinates to attend to them. For example, the chief, the councillor or members of the School Development Committee cannot be ignored by the head of school. The number of meetings that the supervisors attend also take away their attention from the classrooms most of the time.

In addition to attending meetings a lot of their time is consumed by administrative chores at the expense of instructional supervision. This situation also manifests itself vividly when the supervisors relate with their teachers in the classrooms. Whereas most modern models of supervision advocate for colleagueship and collaboration between the teacher and supervisor during the lesson observation, most supervisors find it difficult to de-role and climb down to the level of the teachers. This is because by virtue of being the legitimate authority in the school they are the uncontested bosses of teachers; and it does not come easy therefore for some (if not all of them) to relinquish this status (albeit temporarily) during the classroom visit.

On the other hand, data from the study reveal that teachers also faced a multiplicity of challenges as they attempted to implement the grade seven syllabus. Most of the grade seven teachers could not effectively interpret the syllabus. Coupled with this challenge was the shortage of the syllabus documents for use by the teachers.

\section{Models of supervision utilised by the supervisors' understudy}

Evidence from the study reveals that all the participants and respondents were quite aware of the various models of supervision that can be utilised to 
improve teacher performance and ultimately pupil performance. However, in spite of this vast knowledge about the existence of these progressive models of supervision by both the instructional supervisors, it was clear from the findings that the instructional supervisors were not utilising any specific models of supervision. Instead, they appeared to be randomly using a hotchpotch of versions of one model or the other depending on the motive of the supervisor. As a result of this situation, teachers tended to resent the supervision process since it was full of surprises, unpredictability, chaos as well as disruptive tendencies. On their admission, teachers in the study preferred clinical and development supervision models in their undiluted versions, as these two models promoted teamwork, collegiality, motivation and staff growth. This situation is corroborated by observations by Beach and Reinhartz [18]: who state that:

An important concern in education today is teachers' continuing professional development. The notion that supervising and evaluating teachers might lead to their professional development has traditionally made sense; and certainly the emphasis on teacher evaluation suggests so. However, the literature indicates that for teachers to change themselves or their teaching practices, they must believe in the process. Educational change depends on what teachers do and think; it's as simple and complex as that. And yet, teacher ownership and involvement is not consistent with usual supervisory and evaluation processes.

The information above by Beach and Reinhartz [18] clearly confirms that, what obtains in the schools regarding instructional supervision models is an apparent contradiction of what teachers expect to see happening. It is worth highlighting that most instructional supervisors in the study are aware of what constitutes best practices in instructional supervision and yet they seem to face the other side and do what is applicable within their particular context. The work over load and a congested time table for the supervisors, make it difficult for instructional supervisors to implement the ideal models. They inevitably resort to what is feasible within the context of their operations; which unfortunately is not enough for effective instructional supervision.

The implications of the observation above are that supervisors are mainly concerned with fulfilling the task of instructional supervision regardless of the impact of what their actions have or do not have on the teachers' effectiveness and their general perceptions of the value of the process. Thus, the use of clinical and development supervision models in their full versions would greatly improve the performance of teachers which will inevitably spill over into the performance of pupils particularly the grade seven pupils.

\section{CONCLUSION}

The emphasis on this study has been to highlight the role played by effective instructional supervision in promoting effective teaching and ultimately high student achievement. It has also been argued that many instructional problems encountered by teachers can be resolved if the teachers are guided by an instructional supervision regime that utilizes models that promote teacher professional growth and development. The data in this study seem to strongly suggest that principals in Zimbabwean primary schools are using undemocratic and retrogressive models of instructional supervision. The findings also confirmed conditions of overload and fragmentation in the principal's role. To this end, moving towards effective instructional supervision in Zimbabwean schools therefore, does not suggest a revolution in the transformation of the status-quo. Rather, it advocates for an evolutionary movement towards the establishment of relationships between principals and teachers that are based on cooperation, mutual respect and reliance upon each other as a source of help in working together toward effective instructional supervision.

It is therefore, the conclusion of this researcher that to be effective in their supervision roles, principals should emphasise the utilization of progressive models of supervision. The currently employed practice of a principal making one or two visits per term and calling it instructional supervision is not adequate nor is it effective. Second, the current approach in which a principal observes a class, completes an evaluation and discusses the evaluation; should be modified. The hope for the future as far as this researcher is concerned, is that the principal should become committed to a long term process of initiating and sustaining instructional growth and change for teachers. Principals should help teachers reach their highest potential as classroom practitioners by implementing the most appropriate supervision models.

\section{REFERENCES}

1. Adunola OM. The impact of teachers' teaching methods on the academic performance of primary school pupils in Ijebu-Ode Local Government Area of Ogun State. Ogun State: Ego Booster Books. 2011 Dec.

2. Nwaogu JI. A guide to supervision of instruction in Nigerian Schools. Lagos: University of Lagos.2006.

3. Bush T. Leadership and Management Development in Education. SAGE Publication Ltd 1 Oliver's Yard, 35 City Road London ECIY ISP. 2008.

4. Madziyire NC. Educational leadership and supervision. Harare: University of Zimbabwe.2003.

5. Nyagura LM, Reece JL. The school head as an instructional leader in Zimbabwe secondary schools. Zimbabwe Journal of Educational Research. 1989;1(3):304-41. 
6. Ozigi OA. Hand book on school administration and management. London: McMillan.1997.

7. Harber C, Davies L. Democracy and the postbureaucratic school. School management and effectiveness in developing countries: The postbureaucratic school. 1997:151-66.

8. Marks JR. Hand book of educational supervision. Boston: Allyn and Bacon Inc.1995.

9. Ndebele C. "Supervisory styles in Bulilimagwe District". In published MED thesis. Harare: University of Zimbabwe.2014.

10. McLaughlin J. Successful teacher Evaluation. Alexandra, Association of Supervision and Curriculum Development.2004.

11. Bibi D, Inamullah HM, Irshadullah HM, Khalil M. School Teacher's Views About Supervisor's Strategies For The Improvement Of Instructions. The Shield-Research Journal of Physical Education \& Sports Science.. 2017 May 31;11.

12. Carroll MC. What is the meaning and purpose of supervision? Sydney: Longman. 2007.

13. Sergiovanni T.J and Starratt R. J. (2009). Supervision, Human Perspectives $\left(3^{\text {rd }}\right.$ Edition, New York, McGraw-Hill Book, Company

14. Sergiovanni TJ. Supervision: close look at the models. New York: Longman.2012.

15. Moyo G. Guidelines for the research project. Harare: University of Zimbabwe.2015.

16. Harris B. In-service education: A guide to better practice. Englewood Cliff, N.J: Prentice Hall.2005.

17. Collier D, Daniel Hidalgo F, Olivia Maciuceanu A. Essentially contested concepts: Debates and applications. Journal of political ideologies. 2006 Oct 1;11(3):211-46.

18. Beach DB J and Reinhartz J. Supervision: Focus instructions. New York, N.Y: Harper and Row.2009.

19. Cresswell JW. A concise introduction to mixed methods research. California: Sage Publications.2009.
20. Joyce, B. and Showers, B. (2002). Models of teaching. Englewood Cliffs, N.J. Prentice Hall.

21. Greenblatt, R. B, Cooper, B, S. and Muth, R. (2004). Managing for effective teaching.

Educational Leadership, 41(5): 57-59.

22. Cohen L and Manion L. Research methods in education. London: Longman. 2005.

23. Miles MB and Huberman M. Practical guidelines for school administrators. New York: Teachers College Press.2004.

24. Bailey GD. Teacher self-assessment. A means of improving classroom instruction. Washington DC: National Education Association.2010.

25. Leedy PD. Practical research: Planning and design. New Jersey: Pearson Merrill Prentice Hall.2009.

26. House E. Evaluating with validity. Beverley Hills, CA: Sage.2006.

27. Meighan G. The science of educational research. London: Prentice Hall Inc.2010.

28. Babbie ER. Survey research methods. California: Wadsworth.2010.

29. Gay LR and Mills GE. Educational Research: Competencies for analysis and application, Upper Saddle River N.J. Prentice Hall INC.2006.

30. Bennett B and Kahn JY. Research in education. Boston: Allyn and Bacon.2004.

31. Borg V, Gall A. The methods of quality and quantity research in psychology and educational sciences. Trans. Nasr AR, Oreyzi HR, Abolghasemi M, Pakseresht MJ, Kiamanesh A, Khiyr M. Tehran: Samt Publisher. 2004.

32. Neuman W. Social research methods: qualitative and quantitative approaches. Boston: Allyn and Bacon.2000.

33. Cresswell JW and Clark VL. Designing and conducting mixed methods research. $\left(2^{\text {nd }} e d\right)$. Thousand Oaks, CA: SAGE Publications.2011.

34. Patton GS. From control to supervision. Boston: Allyn and Bacon Inc.2012. 